\title{
Large luteinized follicular cyst of pregnancy
}

\author{
TE Nur ${ }^{1 凶}$, AJ Peea ${ }^{2}$, MM Hossain $^{3}$, AU Husna ${ }^{4}$
}

\begin{abstract}
Ovarian luteinized follicular cyst is a relatively uncommon benign condition characterized by bilateral or solitary ovarian enlargement during pregnancy. A large luteinized follicular cyst can rupture or twist during pregnancy. Few cases of this clinical condition have been reported in literature. A large $(12.5 \times 9 \mathrm{~cm})$ cyst and a live fetus of 8 weeks were detected on ultrasound scan of a 28 year old lady who had lower abdominal pain was the subject of this case report. The cyst was growing rapidly. Laparotomic excision of the cyst, and dilation and curettage was performed. Macroscopically the cyst was $15 \mathrm{~cm}$ in length with smooth regular outer and inner wall. Microscopic examination revealed a large luteinized follicular cyst of pregnancy. A rapidly enlarging ovarian mass in pregnancy poses significant diagnostic problems. Large luteinized cysts of pregnancy are thought to involve stimulation by human chorionic gonadotropin (hCG), or increased tissue sensitivity to hCG. A literature search identified eight previous cases that had been detected prenatally. In summary, large luteinized cysts of pregnancy are an uncommon type of cystic mass particular to pregnancy, characterized by the combination of a benign appearance and a tendency to enlarge rapidly, eventually becoming symptomatic and most often necessitating surgery.
\end{abstract}

Key words: luteinized follicular cyst, pregnancy.

\section{Introduction}

In pregnancy ovarian tumor are relatively common. Now a day, use of ultrasound examination in pregnancy is increasing. The prevalence of ovarian tumor is $2.3-5.4 \%$ being reported in prospective studies. ${ }^{1}$ Most of these are functional cysts, followed by benign cystic teratomas, serous cystadenomas, mucinous cystadenomas, endometriomas and rarely malignant tumors. ${ }^{2}$

Mostly during the first trimester the majority of the ovarian cysts are small $(<5 \mathrm{~cm})$, remain asymptomatic and tend to resolve before birth. ${ }^{3-5}$ Simple cysts of more than 5 $\mathrm{cm}$ in diameter are much less common (representing about $4.0 \%$ of the total). They usually tend to resolve spontaneously; but in comparison with smaller cysts, they are more likely to develop torsion or haemorrhage, require surgical removal during pregnancy or even be associated with malignancy, especially when growing. ${ }^{1,6,7} \mathrm{~A}$ rapidly growing ovarian tumor in pregnancy causes significant diagnostic problems.

Large luteinized cysts of pregnancy are an uncommon type of cystic tumor specific to pregnancy, characterized by the combination of a benign appearance and a tendency to growing rapidly, finally becoming symptomatic and most often requiring surgery. ${ }^{8}$

1. TE Nur, Assistant Professor, Department of Pathology, Gazi Medical College, Khulna.

Email: drtamannaenur@gmail.com

2. AJ Peea, Assistant Professor, Department of Obstetrics \& Gynaecology, Gazi Medical College, Khulna

3. MM Hossain, Assistant Professor, Department of Pathology, Khulna Medical College, Khulna

4. AU Husna, Assistant Professor, Department of Pathology, Prime Medical College, Rangpur 


\section{Case report}

A 28-years-old lady, para-2 (caesarian section) + 1 (abortion) was admitted to Gazi Medical College Hospital at her 8 weeks of gestation with lower abdominal pain on $9^{\text {th }}$ October 2016. On clinical examination, a mobile, non-tender, regular, cystic masse measuring about $12 \times 9 \mathrm{~cm}$ found on left side of lower abdomen. On ultrasound a large $(12.5 \times 9 \mathrm{~cm})$, solitary, unilocular cyst was detected on left adnexa. The patient had an ultrasound report of 2 weeks back which indicated that the mass was very rapidly growing. So the patient was advised for laparotomy. She was also counseled about the teratogenic effect of all drugs used during anesthesia and also risk of abortion after operation. She wished to do termination of pregnancy by dilatation and evacuation and curettage (D\&E\&C) after laparotomy at the same sitting. So, after taking consent laparotomy followed by left sided oophorectomy and D\&E\&C was done on 9th October 2016. On macroscopic examination, the cyst was $15 \mathrm{~cm}$ in diameter \& maximum wall thickness was $1.3 \mathrm{~cm}$; both the outer and inner surfaces were smooth and regular. Microscopically, the inner surface was lined by a single or multiple layers of profoundly luteinized cells with granulosa cell layer. The epithelium had shed in some parts of the wall, preserving a zone of fibrous stroma. The pathological diagnosis was a large single luteinized follicular cyst of pregnancy (Fig. 1).

\section{Discussion}

Ovarian tumors and tumor like masses during pregnancy are uncommon. Most neoplasms are benign, and about $4.0 \%$ are malignant. Tumor-like lesions include pregnancy luteoma, hyperreactioluteinalis, intra follicular granulosa cell proliferation; hilus cell hyperplasia, ectopic decidua and large solitary luteinized follicle cyst of pregnancy (LSLFCP). LSLFCP is a benign tumor. It is of particular interest because of its enormous size and confusion with neoplasms. LSLFCP is a rare lesion; only about 8 cases have been reported in the literature previously. The pathogenesis of LSLFCPP is unclear. Its occurrence during pregnancy
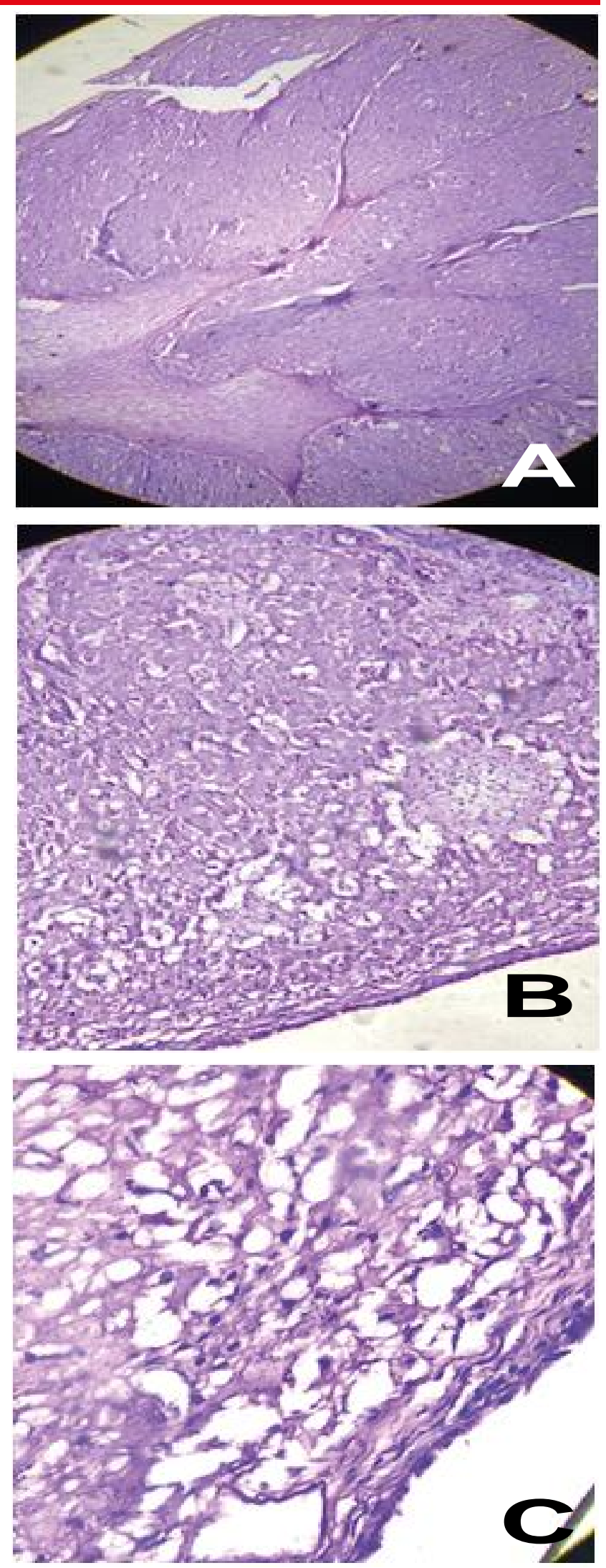

Fig. 1. Microscopic picture of large luteinized follicular cyst of pregnancy. A, low power (4x) view; $B$, medium power (10x) view; $C$, high power (40x) view. 
suggests a role of human chorionic gonadotropin (hCG). Here no hCG level is estimated. Although lined by luteinized cells, the cyst is unlikely to originate from a corpus luteum. The major differential diagnoses include the unilocular cystic granulose cell tumors of both the adult and juvenile types.

Although LSLFCP is in distinguishable grossly from unilocular cystic granulosa tumors, they differ in microscopic features. Unlike LSLFCP that show luteinized cells with focal bizarre nuclei, adult granulosa cell tumor is composed of a monotonous population of granulosa cells usually without luteinisation and bizarre nuclei. Furthermore, nuclear grooves and Call-Exner bodies are seen in granulosa cell tumor but not in LSLFCP. Juvenile granulosa cell tumor is mitotically active while LSLFCP shows absent to occasional mitotic figures. ${ }^{9}$

Another differential diagnosis is a growing simple cyst. These simple cysts are characterized by the combination of a benign appearance and a tendency to enlarge rapidly, eventually becoming symptomatic and most often necessitating surgery.

As with any adnexal tumor, the management options include either follow-up of the patient or surgical removal. Data from series in pregnancy indicate that the risk for torsion in cysts $6-8 \mathrm{~cm}$ in diameter is $22.0 \%{ }^{7}$; and, one in nine cysts of more than $5 \mathrm{~cm}$ will require surgery and this rate increases to $45.0 \%$ for symptomatic cysts. ${ }^{10}$ Although published data are limited specifically in case of large luteinized cysts of pregnancy, their tendency to rapid grow means that they are associated with higher risk, and removal was finally required, either before delivery. ${ }^{10-12}$

\section{Conclusion}

In conclusion, large luteinized follicular cysts of pregnancy are an uncommon type of cystic mass particular to pregnancy, which should be included in the differential diagnostic workup whenever unilocular cystic granulosa cell tumors of both the adult and juvenile types, and a growing simple cyst is encountered. These simple cysts are charac- terized by the combination of a benign appearance and a tendency to enlarge rapidly, eventually becoming symptomatic and most often necessitating surgery.

\section{References}

1. Hummeida ME, Satir AA, Ali AM, Mostafa ERM. Large solitary luteinized follicle cyst of pregnancy and puerperium. Sudan JMS 2015;10(4):169-72.

2. Bignardi $\mathrm{T}$, Condous $\mathrm{G}$. The management of ovarian pathology in pregnancy. Best Pract Res Clin Obstet Gynaecol 2009;23(4):539-48.

3. Condous G, Khalid A, Okaro E, Bourne T. Should we be examining the ovaries in pregnancy? Prevalence and natural history of adnexal pathology detected at first-trimester sonography. Ultrasound Obstet Gynecol 2004;24(1):62-6.

4. Bernhard LM, Klebba PK, Gray DL, Mutch DG. Predictors of persistence of adnexal masses in pregnancy. Obstet Gynecol 1999;93(4):585-9.

5. Glanc $P$, Brofman $N$, Salem S, Kornecki A, Abrams J, Farine D. The prevalence of incidental simple ovarian cysts $>$ or $=3$ $\mathrm{cm}$ detected by transvaginal sonography in early pregnancy. J Obstet Gynaecol Can 2007;29(6):502-6.

6. Zanetta G, Mariani E, Lissoni A, et al. A prospective study of the role of ultrasound in the management of adnexal masses in pregnancy. BJOG 2003;110(6):578-83.

7. Yen CF, Lin SL, Murk W, et al. Risk analysis of torsion and malignancy for adnexal masses during pregnancy. Fertil Steril 2009;91(5):1895-902.

8. Seena KB, Ajithkumar VR, Ansamma PC, Jyothi CR. A rare case of large solitary luteinized follicular cyst of pregnancy and puerperium. Int J Bio 2014;3(3):1844-5.

9. Fang YM, Gomes J, Lysikiewicz A, Maulik D. Massive luteinized follicular cyst of pregnancy. Obstet Gynecol 2005;105:1218-21.

10. Haddad A, Mulvany N, Billson V, Arnstein M. Solitary luteinized follicle cyst of pregnancy. Report of a case with cytologic findings. Acta Cytol 2000;44:454-8. 
11.Wang XY, Vinta MK, Myers S, Fan F. Solitary luteinized follicle cyst of pregnancy and puerperium. Pathol Res Pract 2006;202:471-3.
12.Zhang SY, Huang HF, Tong XM. Solitary luteinized follicle cyst of pregnancy complicated with persistent postpartum vaginal bleeding: case report. Chin Med J (Engl) 2007;120:257-8.

\section{Suggestion for citation of the above:}

Nur TE, Peea AJ, Hossain MM, Husna AU. Large luteinized follicular cyst of pregnancy. Mediscope 2018;5(1):38-41. 